\title{
Knowledge, Attitude and Practice (Kap) on Occupational Noise Exposure among Ambulance Drivers at Hospitals in Klang Valley, Malaysia
}

\author{
MOHAMAD ZULKHAIRIL MOHD ZAKI ${ }^{1}$, HALIZA ABDUL RAHMAN*1,2, AZRIN SHAH ABU BAKAR ${ }^{2}$ \\ ${ }^{1}$ Department of Environmental and Occupational Health, Faculty of Medicine and Health Sciences, Universiti Putra Malaysia 43400, UPM \\ Serdang, Selangor, MALAYSIA. \\ 2Institute for Social Sciences Studies, Putra Infoport, Universiti Putra Malaysia, 43400 Serdang, Selangor, MALAYSIA. \\ *Correspondance: dr.haliza@upm.edu.my Email:dr.haliza@upm.edu.my, Cell: 0397692403
}

\begin{abstract}
There has been a great concern of occupational noise-included hearing loss (NIHL) among health care workers. Prior research revealed that ambulance drivers are at high risk of noise on hearing. The aim of this study is to assess the level of noise emitted from the ambulance siren and knowledge, attitude and practice (KAP) on occupational noise exposure. A cross-sectional study in Klang Valley, Malaysia was conducted from February 2019 to March 2019 among 82 ambulance drivers. Data was collect using a self-administered questionnaire consisting sociodemographic, 13 questions for knowledge, 13 questions on attitude and 13 on the practice toward occupational noise exposure. In addition, a Solo 01dB Sound Level Meter was used to measure the level of noise emitted from the siren of the ambulance. Data was analysis by using SPSS version 22. Average noise level (Laeq) was $88.9 \mathrm{db}$ (A) which can be considered as high than permissible exposure limit specified in Factories and Machinery (Noise Exposure) Regulations 1989. The KAP on occupational noise exposure among respondents were moderate. In addition, there was a significant difference between knowledge and attitude on occupational noise $(p=0.002, r=-0.339)$. Improved of KAP is recommended through conducting training and seminars on occupational noise frequently to ensure high level of KAP among ambulance drivers. Besides, engineering controls such as installing noise barrier were advised to be implemented and enforcement of law should be taken seriously to minimize and void hearing related problems in the near future.
\end{abstract}

\section{INTRODUCTION}

Noise-induced hearing loss (NIHL) is defined as a hearing impairment resulting from exposure to high decibel sound that may exhibit as loss of a narrow range of frequencies, impaired cognitive perception of sound or other impairment, including hyperacusis or tinnitus (Disabled World, 2018). It can be identified through environmental exposure and occupational exposure. Environmental noise includes the emission of noise from traffic, construction sites, railways, industries and airports that may affects to the nearby community. While, noise emitted from a work task, machineries and even the working environment are considered as occupational noise since it will give effects to the population of workers in that work area.

The most common environmental and occupational exposure that hit the highest NIHL prevalent worldwide is noise that is often among mining and construction workers (Tak, Davis \& Calvert, 2009; Engdahl \&Tambs, 2010; Masterson et al., 2013; Masterson, Deddens, Themann, Bertke \& Calvert, 2015). Recently, health care and social assistance workers were found to have a high risk of $\mathrm{HL}$ (Deddens, Themann, Bertke \& Calvert, 2010). Exposure to continuous and intermittent loud noise may slowly leads to NIHL (American College of Occupational and Environmental Medicine, 2012).

Ambulance drivers are often exposed to intermittent noise during driving and sometimes they travel in a long distance since they are responsible in sending the patients to the referral centers which cause NIHL and other hearing related problems. However, only few studies elucidated related to noise exposure towards the driver population. To the best of our knowledge there is no studies have investigated the relationship between occupational noise exposure and knowledge, attitude and practice (KAP) among ambulance drivers particularly in emergency vehicle service since their working routine require them to switch siren on during emergency cases. Therefore, the current study aimed to determine the KAP on occupational noise exposure among ambulance drivers at hospitals in Malaysia.

\section{MATERIALS AND METHODS}

This cross-sectional study was conducted from February 2019 to March 2019 among ambulance drivers. The study was conducted at hospitals in Klang Valley, Selangor area. Hospital Serdang, Hospital Kajang, Hospital Putrajaya and Hospital Kuala Lumpur was obtained from Ministry of Health $(\mathrm{MOH})$. The inclusion criteria were permanent ambulance drivers. Exclusion criteria was staff who are not available during the period of data collection or with existing hearing problems prior to occupation.

The sample size was calculated based on the one proportion for one group formula using $90 \%$ of confidence interval, 1.96 of standard errors and $10 \%$ of desired precision. The sample size needed for the present study was 97 respondents (Aday \& Cornelius, 2006).

Data were collected by using self-administered questionnaire. The questionnaire consists of sociodemographic, age, gender, marital status, race, highest education level, household income, number of dependent, years of employment, current position, department, average working hours in a day, average working hours in a week, shift work, smoking status, hobbies and clinical diagnosis of hearing problems, 13 questions for knowledge comprised of knowledge regarding general aspects about noise, causes of hearing problems, 
risk factors, signs and symptoms of NIHL, treatment, prevention and related law, 13 questions on attitude about the attitude of the respondents towards $\mathrm{NIHL}$, signs and symptoms, health-seeking attitude, prevention and also risk-taking actions and 13 on the practice on occupational noise exposure. In addition, a Solo $01 \mathrm{~dB}$ Sound Level Meter was used to measure the level of noise in the ambulance specifically at the driver's compartment to prove that the noise level supposedly will produce negative impacts to the drivers. The measurement was done for three times to obtain an average value of noise level in the ambulance.

Data was analyzed using an excel spreadsheet and Statistical Package for Social Sciences (SPSS) version 21.0. Data was analyzed using Statistical Package for Social Sciences (SPSS) version 22. Descriptive was used for frequency, percentage, mean and standard deviation. Any possible correlation between knowledge, attitude and practice was determined by Spearman's correlation test. A p-value of $\leq 0.05$ were considered as statistically significant. Ethnical approval for this study was obtained from MREC (Ref. No: NMRR-18-2950-44709) since the requirement for a study to be conducted among $\mathrm{MOH}$ personnel need approval and the Research Committee for Research Involving Human Subjects, Universiti Putra Malaysia (UPM/TNCPI/RMC/1.4.18.2).

\section{RESULTS}

A total of 97 respondents were approached to participate in this study, however, only 82 respondents completed the study and were included in the final analysis. The total response rate was $84.5 \%$.

Majority of the respondents were male (100\%) and Malay $(81 \%)$. For age distribution, most of the respondents age ranged from 31 to 40 years old and 41 to 50 years old, which marked $(58.0 \%)$ and $(22.0 \%)$ respectively. The reported ages had the youngest respondent was at age 21 30 years old and above years old $(16.0 \%)$ and the oldest respondent at 51 years old $(4.0 \%)$.

Meanwhile, the distribution of respondent by the years of employment showed that majority among them worked between $1-5$ years $(52.0 \%)$. There were only $(10.0 \%)$ of the respondents who worked for below than 1 year and the remaining has worked for $6-10$ years $(18.0 \%)$ and more than 11 years $(20.0 \%)$ respectively.

The sound level in the ambulance was specifically measured at the driver's compartment. The measurement was conducted for three times to obtain average. For the first measurement which is right after the siren was switched on, the sound level recorded was $88.5 \mathrm{db}(\mathrm{A})$. The next measurement was conducted for after a while the siren was switched on and recorded $90.6 \mathrm{db}(\mathrm{A})$. The third measurement was obtained once the siren was already going to switch off, which recorded $87.8 \mathrm{db}(A)$. Thus, the average sound level (Laeq) in the ambulance recorded was $88.9 \mathrm{db}(\mathrm{A})$.

The result of the survey on knowledge showed that the majority of participants had a good knowledge (74.4\%) regarding the importance of the law in Malaysia that protects workers who are exposed to noise in the workplace which is Factories and Machinery (Noise Regulations) 1989. More than half of the respondents $(53.7 \%)$ stated that pus discharge from ear is an early sign of deafness due to exposure to loud noise. Majority of the respondents $(78.0 \%)$ noticeable that the item it's the responsibility of the employees to wear ear plugs while working.

For the attitude on occupational noise exposure, $40.2 \%$ (33) of the respondents disagreed to the statement that they are not worried if they can't hear properly after working in noisy place because it is only temporary while another $29.3 \%$ (24) were uncertain. Furthermore, 40.2\% (33) of respondents agreed that they should use ear plug to avoid becoming deaf due to noise but $25.6 \%$ (25) were uncertain. They also agreed that they should inform the employers if the siren noise is suddenly noisier than before $46.3 \%$ (38). Besides, 42.7\% (32) also agreed to statement stated that training and health education for workers regarding methods on self-protection towards noise should be done from time to time. Moreover, $31.7 \%$ (26) of the respondents agreed that only employers need to know in detail about the Occupational Safety and Health Act 1994 while $29.3 \%$ (24) were uncertain.

In terms of practice on occupational noise exposure, about the half of the workers $(67.1 \%)$ never wear ear plugs when working. This is very important issue since hearing related problem are mostly irreversible and not wearing ear plugs in noisy workplace may increases the tendency of the workers to experience symptoms such as ringing in ears, inability to hear conversation effectively and need to shout when talking to people. Then, $52.4 \%$ (43) of the respondents reported that they never attended any seminar or course on deafness due to work and $54.9 \%$ (45) reported that their workplace only conducted training on health and safety seldomly. Table 1 shows the sociodemographic characteristics of the respondents, while Table 2 shows the knowledge on occupational noise exposure among respondents. Lastly Table 3 and 4 show the attitude and practice on occupational noise exposure among respondents.

Table 1: Socio- demographic characteristics of the respondent $(\mathrm{N}=82)$

\begin{tabular}{|l|l|l|}
\hline Variable & Frequency $(\mathbf{n})$ & Percentage(\%) \\
\hline Ethnic & & \\
\hline Malay & 81 & 98.7 \\
\hline India & 1 & 1.21 \\
\hline Age & & \\
\hline $21-31$ & & 16.0 \\
\hline $31-40$ & & 58.0 \\
\hline $41-50$ & & 22.0 \\
\hline 51 years and above & & 4.0 \\
\hline Years of employment & & \\
\hline Below 1 years & & 10.0 \\
\hline 1 to 5 years & & 52.0 \\
\hline 6 to 10 years & 18.0 \\
\hline 11 years and above & & 20.0 \\
\hline
\end{tabular}


Table 2: Knowledge on occupational noise exposure among respondents $(\mathrm{N}=82)$

\begin{tabular}{|c|c|c|c|}
\hline No. & Questions & Answer & Frequency (\%) \\
\hline \multirow[t]{2}{*}{1.} & \multirow{2}{*}{$\begin{array}{l}\text { Deafness due to noise is a more common problem among } \\
\text { ambulance drivers as compared to other healthcare workers }\end{array}$} & True & $52(63.4)$ \\
\hline & & False & $30(36.6)$ \\
\hline \multirow[t]{2}{*}{2.} & \multirow{2}{*}{$\begin{array}{l}\text { High exposure of noise from ambulance siren can cause } \\
\text { hearing loss to the driver }\end{array}$} & True & $39(47.6)$ \\
\hline & & False & $43(52.4)$ \\
\hline \multirow[t]{2}{*}{3.} & \multirow{2}{*}{$\begin{array}{l}\text { Deafness can occur even if a worker is exposed to intermittent } \\
\text { noise for a long period }\end{array}$} & True & $44(53.7)$ \\
\hline & & False & $38(46.3)$ \\
\hline \multirow[t]{2}{*}{4.} & \multirow{2}{*}{$\begin{array}{l}\text { Hobbies like shooting and listening to loud music can cause } \\
\text { deafness }\end{array}$} & True & $55(67.1)$ \\
\hline & & False & $27(32.9)$ \\
\hline \multirow[t]{2}{*}{5.} & \multirow{2}{*}{$\begin{array}{l}\text { If people are exposed to noise, men are at higher risk of } \\
\text { deafness than women }\end{array}$} & True & $53(64.6)$ \\
\hline & & False & $29(35.4)$ \\
\hline \multirow[t]{2}{*}{6.} & \multirow{2}{*}{$\begin{array}{l}\text { Pus discharge from ear is an early sign of deafness due to } \\
\text { exposure to loud noise }\end{array}$} & True & $44(53.7)$ \\
\hline & & False & 38 (46.3) \\
\hline \multirow[t]{2}{*}{7.} & \multirow[t]{2}{*}{ Deafness due to noise can treated by taking medicine } & True & $35(42.7)$ \\
\hline & & False & $47(57.3)$ \\
\hline \multirow[t]{2}{*}{8.} & \multirow{2}{*}{$\begin{array}{l}\text { Deafness due to noise will recover to normal if a person is no } \\
\text { longer exposed to excessive noise }\end{array}$} & True & $41(50.0)$ \\
\hline & & False & $41(50.0)$ \\
\hline \multirow[t]{2}{*}{9.} & \multirow{2}{*}{$\begin{array}{l}\text { There is law in Malaysia that protects workers who are } \\
\text { exposed to noise in the workplace }\end{array}$} & True & $61(74.4)$ \\
\hline & & False & $21(25.6)$ \\
\hline \multirow[t]{2}{*}{10.} & \multirow[t]{2}{*}{ It's the responsibility of the employer to provide ear plugs } & True & $64(78.0)$ \\
\hline & & False & $18(22.0)$ \\
\hline \multirow[t]{2}{*}{11.} & \multirow{2}{*}{$\begin{array}{l}\text { It's the responsibility of the employees to wear ear plugs while } \\
\text { working }\end{array}$} & True & 65 (79.3) \\
\hline & & False & $17(20.7)$ \\
\hline \multirow[t]{2}{*}{12.} & \multirow{2}{*}{$\begin{array}{l}\text { Diseases like hypertension, heart attack and stroke may } \\
\text { contribute to the development of hearing problems }\end{array}$} & True & $30(36.6)$ \\
\hline & & False & $52(63.4)$ \\
\hline \multirow[t]{2}{*}{13.} & \multirow{2}{*}{$\begin{array}{l}\text { In your knowledge, does any of your colleagues has } \\
\text { experienced hearing problems due to work? }\end{array}$} & True & $32(39.0)$ \\
\hline & & False & $50(61.0)$ \\
\hline
\end{tabular}

Table 3: Attitude on occupational noise exposure among respondents $(\mathrm{N}=82)$

\begin{tabular}{|l|l|l|l|l|l|l|}
\hline No. & Questions & \multicolumn{3}{l|}{ Frequency $\%$} & $\mathbf{3}$ \\
\cline { 2 - 5 } & & $\mathbf{1}$ & $\mathbf{2}$ & $\mathbf{3}$ \\
\hline 1. & I'm not bothered by noise in the workplace & $13(15.9)$ & $32(39.0)$ & $22(26.8)$ & $12(14.6)$ & $3(3.7)$ \\
\hline 2. & $\begin{array}{l}\text { Exposure to noise while driving ambulance would not make } \\
\text { me deaf }\end{array}$ & $9(11.0)$ & $20(24.4)$ & $34(41.5)$ & $18(22.0)$ & $1(1.2)$ \\
\hline 3. & $\begin{array}{l}\text { I'm not worried if I can't hear properly after working in noisy } \\
\text { places because it is only temporary }\end{array}$ & $14(17.1)$ & $33(40.2)$ & $24(29.3)$ & $9(11.0)$ & $2(2.4)$ \\
\hline 4. & Excessive exposure to noise can cause permanent deafness & $5(6.1)$ & $13(15.9)$ & $29(35.4)$ & $27(32.9)$ & $8(9.8)$ \\
\hline 5. & $\begin{array}{l}\text { I'll seek traditional medicine if I have deafness in the early } \\
\text { stage }\end{array}$ & $11(13.4)$ & $30(36.6)$ & $28(34.1)$ & $10(12.2)$ & $3(3.7)$ \\
\hline 6. & $\begin{array}{l}\text { I don't have to get early treatment if I suspect in the early } \\
\text { stage because it is self-limiting }\end{array}$ & $9(11.0)$ & $43(52.4)$ & $24(29.3)$ & $6(7.3)$ & $0(0.0)$ \\
\hline 7. & $\begin{array}{l}\text { I don't have to inform my employer if my hearing starts to } \\
\text { deteriorate }\end{array}$ & $13(15.9)$ & $39(47.6)$ & $22(26.8)$ & $5(6.1)$ & $3(3.7)$ \\
\hline 8. & $\begin{array}{l}\text { Preventive measures towards deafness due to occupational } \\
\text { noise is important }\end{array}$ & $5(6.10$ & $31(37.8)$ & $4(4.9)$ & $21(25.6)$ & $21(25.6)$ \\
\hline 9. & $\begin{array}{l}\text { We should use the ear plug to avoid becoming deaf due to } \\
\text { noise }\end{array}$ & $2(2.4)$ & $12(14.6)$ & $21(25.6)$ & $33(40.2)$ & $14(17.1)$ \\
\hline 10. & $\begin{array}{l}\text { Periodic audiometry assessment can detect deafness due to } \\
\text { noise in the workplace }\end{array}$ & $4(4.9)$ & $21(25.6)$ & $16(19.5)$ & $32(39.0)$ & $9(11.0)$ \\
\hline 11. & $\begin{array}{l}\text { We should inform the employers if the siren noise is suddenly } \\
\text { noisier than before }\end{array}$ & $3(3.7)$ & $12(14.6)$ & $19(23.2)$ & $38(46.3)$ & $10(12.2)$ \\
\hline 12. & $\begin{array}{l}\text { Training and health education for workers regarding methods } \\
\text { on self-protection towards noise should be done from time to } \\
\text { time }\end{array}$ & $2(2.4)$ & $16(19.5)$ & $17(20.7)$ & $35(42.7)$ & $12(14.6)$ \\
\hline 13. & $\begin{array}{l}\text { Only employers need to know in detail about the Occupational } \\
\text { Safety and Health Act 1994 }\end{array}$ & $6(7.3)$ & $17(20.7)$ & $24(29.3)$ & $26(31.7)$ & $9(11.0)$ \\
\hline
\end{tabular}

Table 4: Practice on occupational noise exposure among the respondents $(\mathrm{N}=82)$

\begin{tabular}{|l|l|l|l|l|l|}
\hline No. & Questions & Frequency (\%) & $\mathbf{3}$ & $\mathbf{4}$ \\
\cline { 3 - 5 } & & $\mathbf{1}$ & $\mathbf{2}$ & $\mathbf{3}(6.1)$ & $0(0.0)$ \\
\hline 1. & I always use ear plugs when working & $55(67.1)$ & $22(26.8)$ & $5(2)$. \\
\hline 2. & $\begin{array}{l}\text { I undergo ear examinations by a doctor to detect deafness } \\
\text { due to noise }\end{array}$ & $36(43.9)$ & $27(32.9)$ & $17(20.7)$ & $2(2.4)$ \\
\hline 3. & I try to avoid noise as much as possible when I'm working & $15(18.3)$ & $39(47.6)$ & $17(20.7)$ & $11(13.4)$ \\
\hline 4. & $\begin{array}{l}\text { When ear plugs are not available, I use whatever that is } \\
\text { available (e.g. cotton) to protect my ear from noise }\end{array}$ & $31(37.8)$ & $30(36.6)$ & $18(22.0)$ & $3(3.7)$ \\
\hline
\end{tabular}




\begin{tabular}{|l|l|l|l|l|l|}
\hline 5. & I discuss with my employers if the ear plug is broken & $43(52.4)$ & $19(23.2)$ & $14(17.1)$ & $6(7.3)$ \\
\hline 6. & Have you ever undergone an audiometry assessment? & $41(50.0)$ & $24(29.3)$ & $16(19.5)$ & $1(1.2)$ \\
\hline 7. & $\begin{array}{l}\text { Has the employer arranged for their workers to undergo } \\
\text { medical examination from time to time? }\end{array}$ & $18(22.0)$ & $43(52.4)$ & $18(22.0)$ & $3(3.7)$ \\
\hline 8. & $\begin{array}{l}\text { Have you attended any seminar or course on deafness due to } \\
\text { noise? }\end{array}$ & $43(52.4)$ & $25(30.5)$ & $10(12.2)$ & $4(4.9)$ \\
\hline 9. & Has your workplace conducted training on health and safety? & $13(15.9)$ & $45(54.9)$ & $18(22.0)$ & $6(7.3)$ \\
\hline 10. & I avoid turning on radio during driving & $12(14.6)$ & $45(54.9)$ & $18(22.0)$ & $7(8.5)$ \\
\hline 11. & $\begin{array}{l}\text { I avoid hobbies like listening to loud music, clubbing, karaoke, } \\
\text { shooting and watching movies }\end{array}$ & $12(14.6)$ & $39(47.6)$ & $19(23.2)$ & $12(14.6)$ \\
\hline 12. & $\begin{array}{l}\text { I practice healthy lifestyles by doing exercise during my leisure } \\
\text { time }\end{array}$ & $10(12.2)$ & $46(56.1)$ & $15(18.3)$ & $11(13.4)$ \\
\hline 13. & I try to sleep for an average of 6 hours and more daily & $15(18.3)$ & $33(40.2)$ & $20(24.4)$ & $14(17.1)$ \\
\hline
\end{tabular}

Table 5: Association between KAP on occupational noise exposure $(\mathrm{N}=82)$

\begin{tabular}{|l|l|l|l|l|l|l|}
\hline & Knowledge & Attitude & Practice \\
\hline & $\mathrm{r}$ & $\mathrm{p}$-value & $\mathrm{r}$ & $\mathrm{p}$-value & $\mathrm{r}$ & $\mathrm{p}$-value \\
\hline Knowledge & - & - & -0.339 & $\mathbf{\mathbf { 0 . 0 0 2 } ^ { * }}$ & -0.002 & 0.985 \\
\hline Attitude & -0.339 & $\mathbf{0 . 0 0 2}$ & - & - & -0.207 & 0.062 \\
\hline Practice & -0.002 & 0.985 & -0.207 & 0.062 & - & - \\
\hline
\end{tabular}

†analysed using Spearman correlation test

${ }^{*}$ Statistically significant at $p<0.05$

Table 5 shows that there was a significant different between knowledge and attitude on occupational noise exposure among respondents $(r=-0.339, p=0.002)$. However, no significant difference was reported for other variables.

\section{DISCUSSION}

The findings of this study showed that the average noise level (Laeq) was $88.9 \mathrm{db}(\mathrm{A})$ which can be considered as high than permissible exposure limit specified in Factories and Machinery (Noise Exposure) Regulations 1989, where no employee shall be exposed to noise level exceeding equivalent continuous sound level of $90 \mathrm{~dB}(\mathrm{~A})$ for 8 hours of working or exceeding the limits specified in the first schedule. Similar findings were found noise level found was greater than $85 \mathrm{~dB}(\mathrm{~A})$ among ambulance crew (Oliveira, Silva, Magalhães \& Santos, 2015). This might be the proximity of the machine to the workers' ears increase the high recorded noise exposure. Hence, it may contribute to hearing problems among the ambulance drivers. Hisama and Annua (2018) stated the criterion for action (action level) adopted is $85 \mathrm{~dB}(\mathrm{~A})$ that necessitates the implementation of activities to reduce the risk of NIHL. Also, it is renamed as Occupational Safety and Health (Noise Exposure) Regulation 2019 and requires every employer to ensure that none of his employee is exposed to the daily noise exposure level exceeding $85 \mathrm{db}(A)$ or daily personal noise dose exceeding hundred percent.

It was found that the majority $(59.0 \%)$ of the respondents have a moderate level of knowledge while respondents with low and high knowledge accounts for $12.0 \%$ and $29.0 \%$ respectively. For attitude, $58.0 \%$ of the respondents scored moderately while respondents with poor and good attitude reported was $21.0 \%$ for both. Then, $65.0 \%$ of the respondents have shown a moderate practice on occupational noise exposure. Only $17.0 \%$ of the respondents have shown poor practices while another $18.0 \%$ shown good practices. This is an important point out to be considered in any shared responsibility between them and the employer to know in detail for personal hearing protective included in the law as well as they need to know what are their responsibilities as well in high-noise workplaces (Taban et al., 2016).
There was a significant different between knowledge and attitude on occupational noise exposure among participants $(r=-0.339, p=0.002)$. As shown in previous studies showed that knowledge of hearing health is increased with a significant change in attitude (Chung et al., 2005). Possible cause for attitude differences between countries is the influence of information and knowledge in achieving attitude and behavioral change in health risk behaviours (Widén et al., 2006).

\section{CONCLUSION}

The result of this study showed a high noise level among ambulance drivers even though there is no regulation found regarding permissible exposure limit for noise in ambulance. The KAP on occupational noise exposure among ambulance drivers in this study is moderate. In addition, the association between knowledge and attitude on occupational noise exposure were found to be significant on occupational noise exposure. Nonetheless, there were no significant association found between years of employment with level of KAP of the respondents. Therefore, is it suggested that both regulation and training on occupational health give serious attention to this particular aspect to reduce the incidence of the siren noise from the drivers.

Acknowledgement: The authors would like to thank the directors and head department of emergency and trauma of Hospital Serdang, Hospital Kajang, Hospital Putrajaya, and Hospital Kuala Lumpur for giving permission to conduct the research. The authors also would like to show gratitude to all ambulance drivers who willingly participated in this study.

\section{REFERENCES}

1. Aday LA, Cornelius LJ. Designing and Conducting Health Surveys: A Comprehensive Guide (Third edition). San Francisco, California, United States: Jossey-Bass,2006. 
2. Deddens JA, Themann CL, Bertke S, Calvert GM. Trends in worker hearing loss by industry sector, 1981-2010. Am J Indust Med. 2015; 56:670-681.

3. Disabled World. Noise Induced Hearing Loss (NIHL): Causes \& Prevention, 2018. Available from: https://www.disabledworld.com/.

4. Engdahl B, Tambs K. Occupation and the risk of hearing impairment-results from the Nord-Trondelag study on hearing loss. Scand J Work Environ Health. 2010; 36:250257.

5. Hisama A, Anuaa SM. Noise Exposure and Hearing Symptoms Among Laundry Workers andMechanical Cutters in a Teaching Hospital. Journal of Occupational Safety and Health 2018; 15(1):35-41.

6. Masterson E, Tak S, Themann CL, et al. Prevalence of hearing loss in the United States by industry. Am J Indust Med. 2013; 56:670-681.

7. Masterson E, Deddens JA, Themann CL, Bertke S, Calvert GM. Trends in worker hearing loss by industry sector, 19812010. Am J Indust Med. 2015; 56:670-681.
8. Oliveira RC, da Silva TCA, Magalhães MC, Santos JN. Occupational Exposure to Noise by Ambulance Crew. Revista CEFAC: Atualizacao Cientifica em Fonoaudiologia e Educacao. 2015; 17(3):847-853.

9. Taban E, Yazdani Aval M, Ahmadi O, Miri M, Fereidan M, et al. Study of Personal Hearing Protection Devices Usage in Kashan Carpet Industry Workers, Health Scope. 2016; 5(4): e35250.

10. Tak SW, Davis RR, Calvert GM. Exposure to hazardous workplace noise and the use of hearing protection devices among US workers: NHANES, 1999-2004. Am J Indust Med. 2009; 52:358-371.

11. Widén S E, Holmes A E, Erlandsson S I. Reported Hearing Protection Use in Young Adults from Sweden and The USA: Effects of Attitude and Gender. Int. J. Audiol.. 2006; 45(5), 273-280. 